\title{
Towards a Critical Pedagogy of Peace Education*
}

\section{KEY WORDS}

critical pedagogy, pedagogy of hope, peace education, Paulo Freire

\begin{abstract}
Shapiro Svi, Towards a Critical Pedagogy of Peace Education [W stronę pedagogiki krytycznej edukacji dla pokoju]. Kultura - Społeczeństwo Edukacja nr 1(7), 2015, Poznań 2015, pp. 7-20, Adam Mickiewicz University Press. ISBN 978-83-232-2944-5. ISSN 2300-0422

This article tackles the issue of critical pedagogy in regards to education for peace. Peace education is here seen as a holistic process of development of human potential to coexist in a less violent manner. This problem is significant for example in the context of South Africa, which is being explained in this paper. Another example of this kind of pedagogy is related to the Jewish and Greek concepts of Tikkun Olam and Parrhesia. Finally they are being emphasized the issues of empathy and pedagogy pf hope.
\end{abstract}

\section{Factories of conformity}

The ideology of moral and social conformity is by no means the only force shaping education today in ways that exclude a serious concern with questions of war, violence and dehumanization. More and more teaching is gripped by the mania of measurable outcomes, objectively assessed performance, and standardized testing. Fueled by the panic of falling standards and inadequate accountability politicians, business leaders and others have driven our schools into become testing factories in which only those things that are quantifiable have any real curricular value. And a regime that stresses constant measurement of student achievement shapes life for our children. The grim consequences of all this are

\footnotetext{
* This paper draws on my guest lecture given in the School of Education, at the Adam Mickiewicz University, October, 2014.
} 
now well documented. Students face ever mounting pressure to succeed in a hothouse competitive environment. It is no surprise that we see increasing signs of stress and anxiety among young people. (In the US and UK this mounting level of anxiety has led to well-publicized calls for a change in direction away from the emphasis on high stakes testing). More and more teachers are forced to make the classroom a place in which test performance is the central activity (Shapiro, 2006). Preparation and rehearsal for the test occupies much of classroom time. The relentlessness of this process drives away some of the best and most creative teachers who are looking for something more stimulating and humane in their work. And most sadly this regime of demonstrable accountability empties education of anything that cannot be measured and tested in a standardized form. The result is a curriculum that becomes increasingly narrow and constrained, eliminating anything that might demand more complex, interpretive or imaginative responses from students. The arts and other forms of creative activity become marginalized or left out entirely (Ravitch, 2014). Or they too must be transformed into more rigidly structured and 'objective' forms of learning. There is less and less time in the classroom for those things that depend on dialogue, discussion and the development of respectful and tolerant social relationships. In other words, those skills and dispositions that are necessary to an engaged and reflective civic life. The classroom becomes a place less and less concerned with students as holistic beings; educating individuals in the totality of their lives as moral, intellectual, imaginative and spiritual persons. In this sense the goal of peace education which demands educating students in the fullness of their humanity is negated by the limited and narrowly defined focus that today subsumes our schools. The call to focus on peace in our education is necessarily a call to reenvision the very way we educate young people away from the deadening and confined forms that presently dominate our classrooms.

Educating for peace is always a holistic process. It means recognizing that if human beings are to move towards a less violent, more cooperative and caring mode of existence, it will require the broad development of all our potentialities. It will demand change and development in our social consciousness and our capacity to reason; in our sentient life as feeling and embodied creatures; in our moral sensitivity and conscience; and in an awakening or enlargement of our spiritual awareness. The kind of education that schools are now focused upon is hardly capable of bringing about such change. The emphasis on performance and measurable outcomes leads to a denial of the relevance of anything that cannot be immediately turned into quantifiable data. An empirically-driven education can have little relevance to the quest for moral and spiritual change with its more intangible but, nonetheless, crucial nature. Nor can it speak to an educa- 
tion that is about our emotional lives with its far more complex and interior qualities. The attempt to reduce human experience to a series of test bubbles rests on a simplistic, cartoon-like version of individual complexity. And can there be any doubt as to the conflict between a standardized education with its 'one right answer,' and an education that seeks to encourage a questioning and challenging of a single truth, and an appreciation for multiple ways of understanding the world and our lives (Giroux, 2011).

Finding our way to a more peaceful world will mean constructing a world that is more just, more compassionate, more democratic and more reverential of all life. Education can and should be an important component in pursuing this goal. What and how we teach our children is surely a critical dimension in the social and moral changes that we so urgently need. But it will mean a bold and radical re-visioning of both the purpose of education and the way we seek to teach.

\section{Elements of a critical peace education}

Several years ago I was fortunate enough to attend a workshop at the University of Haifa in Israel devoted to 'Peace Education Research.' This workshop brought together both academic scholars and those directly engaged in various forms of peace education (Salamon and Nevo, 2002). Many of the participants were from places that had experienced severe episodes of communal violence. In addition to those from Israel - both Palestinians and Jews - there were people from South Africa, Ireland, Bosnia, Rwanda, Spain, Norway, as well as other countries. Naively, I hoped, at that time I would learn from these experienced researchers and practitioners exactly how one went about educating for peace. My social science training led me to expect there would be some kind of scientifically fool-proof method of achieving peaceful relationships between hitherto warring groups. I learned that nothing could be farther from the truth. Even the commonly practiced 'contact hypothesis' that assumed that by bringing individuals together in a supportive social and educational setting in order to get to know each other as real human beings, and so undo prejudices and hostilities, was found to have only limited effect. After a while, if no other political or institutional changes took place, and under the cultural pressures at home, old patterns of animosity reemerged. What I did find at this workshop, however, was not a single method or approach to peace education but a variety of experiments that used different modalities and media. These approaches met with varying degrees of success, though the long-term consequences of all of them were hard to assess. Some of 
these provided shared social and educational experiences for children from hostile communities in order to 'deconstruct the otherness' of the protagonists; others had developed text books that helped students understand and discover the world from the experience of the other. Some engaged in travel to places that evoked the painful history and suffering of the 'enemy' community. There were projects that brought groups of children together around shared art, music and dance projects. Some placed young people in the homes and families of the other community. Some involved joint political projects to create more socially just situations and contexts. Some simply attempted to have children experience the other's holiday festivals and celebrations. By the end of all this I concluded that any approach to peace education would be far more messy. It would involve a multiplicity of approaches, interventions, and educational initiatives. There would be no 'one size fits all method. Yet out of this mélange of possible directions for affecting change among young people, away from violence, hate, prejudice and misunderstanding, I also saw that were certain shared principles and concepts that ran through all of the experiments. And in the following pages I want to outline, if only briefly, five principles that I believe represent essential dimensions of a critical pedagogy of peace - an education for peace My concern will be to describe some of those moral, social and spiritual aspects of human behavior and dispositions that are needed in order to bring about that transformation towards peace in our collective lives.

\section{Educating for community}

I start with the African notion of ubuntu. Cape Town Archbishop Desmond Tutu suggests that the African term ubuntu means that one cannot exist as a human being in isolation. It speaks, he says, about our interconnectedness, our belonging to a greater whole (Tutu, 1999). You cannot be human by yourself. Contemporary culture teaches us to think of ourselves as just individuals, separated from one another. Schools usually provide a powerful vehicle for this ideology of the separate self. Most of what is defined as success (or failure) is a matter of individual achievement and performance. And, of course, what individuals achieve is always in invidious comparison to the success or failure of others. Likewise consumer culture is always about the promise of improving the quality of our lives or social status through what we as individuals own or can purchase. It is not surprising that this culture produces a world of so much loneliness, disconnection from others, and conflict. It teaches us to see ourselves alone in a sea of other lonely strivers after satisfaction, validation or success. At its core it de- 
nies the simple reality of the oneness of human existence, and with it the recognition that it is through our connectedness to others that we experience the deepest and richest satisfactions and joys of life (Lerner, 2006).

To affirm the concept of ubuntu, and to educate for its radical promise, means a very different focus for what we wish students to learn, morally, socially and spiritually. In the first place it means that the school and the classroom move away from the relentless focus on the success and failure of the individual that is inscribed in every aspect of schooling. It means that we come to see our achievements and failures as learners as the shared product of our communal efforts, not as something earned and owned by the lone student. The classroom emphasizes the community's achievements over the success of the individual (Palmer, 2004). The 'culture of separated desks' in which each student is a lonely runner in the race for success gives way to a classroom ambience of communal support, the sharing of knowledge and information, and mutual respect for each person's contributions. Beyond this the message of education must be one that runs counter to the individualistic and competitive message of the consumer culture; human fulfillment is found in how we serve, support and care for the wellbeing of other human beings (Eisler, 2008). And contrary to our dualist preferences and prejudices, our highest moral and social obligation is to serve humanity undivided by markers of nationality, race, gender, sexuality and ethnicity. The educational message of ubuntu is one that resists all those things that separate and isolate human beings from one another - that cause us to see others as disconnected from oneself, to demonize others, to see them as of lesser value than ourselves. It leads us to question the moral environment of the school, the social relationships of the classroom, the messages found in our texts, as well as the broader messages of the culture within which we live. In each case we must ask does what we learn from these things help us to recognize and realize our mutual connectedness and interdependence as human beings? Does it enable us to experience the profound fulfillment and joy that comes from human sociability and interaction? Or does it thwart, undermine and deny them? And to what extent are we coming to see ourselves as part of a global community in which particular connections to ethnicity, nation etc. are less important than the ties we have with the whole human family. Do our educational experiences nurture and encourage this sense of global human identity?

\section{Educating for a life of meaning}

The Second point of my pedagogy draws on the Jewish concept of tikkun olam. Tikkun Olam speaks to the need among human beings for an authentic life of 
meaning, and the responsibility of education to facilitate such a quest (Shapiro, 2010). It rests on the mythic Hebrew vision of a world which has overcome division and fragmentation and become whole and united as a single caring community. The struggle for such a world becomes, in this vision, the overriding moral responsibility of human beings in this life. More than this, it is in the act of trying to create a world of compassionate and loving connection in the face of all the divisions, injustices, conflicts and suffering that beset human beings, that we are able to find the most profound sense of meaning in our lives. The message of tikkun olam is one that speaks out against everything that separates and fragments our world-war, torture, social injustice, nationalism, tribalism, racism, sexism, homophobia, religious intolerance, and excessive competition, must be called into question and challenged.

Tikkun Olam speaks to 'the repair' of our world.' And it is through our engagement in this act of repair work that human beings find the meaning that animates a purposeful life. To educate in this spirit means to encourage students to see their lives in terms of the contribution each might make to healing the brokenness of our world; to see how they may act to redress hatred, racism, intolerance, indignity and injustice - all those things that fragment and divide our world. It offers students a counter-vision to the self-interested message so relentlessly pounded out by the culture of capitalism and modernity. It suggests a broad moral, social and spiritual framework for how they may think about the direction of their lives. The search for a life of meaning can never be far from the goal of educating for peace. Education today has lost its most profound purpose - engagement with what it means to live meaningfully and purposefully (Lerner, 2006). Instead schooling has become the soil for an arid and soulless focus of human energy and ambition; better test scores, higher grades, greater student retention, etc. The school becomes like a black box in which inputs are measured against outputs. Our obsession with numbers, output and averages has meant we have forgotten our responsibility to a younger generation to provide them with the opportunity for serious reflection on the nature of a purposeful life.

The absence of such opportunity is especially sad given the demonstrable crisis of meaning in our larger culture. It is a crisis that manifests itself in record levels of teenage suicides and emotional disorders, in widespread feelings of despair, loneliness, emotional emptiness, and in the turn towards self-destructive and violent behavior. None of this can be that surprising given the dehumanizing nature of so much of the wider culture through which young people are expected to discern their life goals and aspirations. It surrounds them with a world in which the most important things are celebrity, fame, wealth, and appearance (West, 2004). In such a world time is reduced to the most immediate experience, 
episode or moment. And nothing is more important than the search for the next exhilarating and optimal high. As observers like Zygmunt Bauman have pointed out, it is but a short step from this kind of cultural exposure and socialization to the despair and anxiety that leads to violence and destruction -whether this is inflicted on others or on oneself (Bauman, 2007).

\section{Educating for critical citizenship}

My third principle draws on the Greek concepts of parrhesia and hermeneutics and concerns the quest for the education of a courageously articulate citizenry. Peace education always inhabits that in-between zone where the 'what is' encounters the 'what might be'. Henry Giroux has referred to this as the voice that speaks in both 'the language of critique and in the language of possibility' (Giroux, 2001). Others have referred to it as a 'critical utopianism' in which the imagined world of human dignity, justice and peace is held up against the realities of our torn and divided world. Parrhesia is the fearless voice that challenges and questions the world's unnecessary suffering (Aronowitz, 2008).

Few who are concerned with driving policy in public education concern themselves much with parrhesia and critical speech. Education today is overwhelmingly concerned with things that have little to do with developing voices that can question and challenge what is in our world. Indeed, what we see everywhere is a focus on a one-size fits all kind of education that is more about conformity in thinking than anything else. The focus on standardized tests and measures of 'performance' in our classrooms has induced a kind of learning where students and teachers can do little else but be concerned with getting the one correct answer on the test sheet. There is precious little opportunity in all this for the kind of unconventional thinking that questions the accepted understanding of how things are. There is little time for those bold and outrageous challenges to the accepted nature of things. The present 'regime' in education is one that is all about finding somebody else's idea of the one right answer. This conformity is reinforced not just through the medium of standardized forms of assessment but also through the sterility of what constitutes the learning space. Now this space mostly excludes those very things that are most salient to the direction and quality of young people's lives; sexuality, spiritual and religious faith, the impact of the media and the content of popular culture, war and violence, race and cultural difference, power and politics. Remove these things and we are left with a classroom that offers no possibility of the kind of passionate engagement that stirs us to find our voices and speak our truth to others who share our world (Hooks, 2010). 
The exercise of parrhesia in the classroom is a practical matter. It means transforming these spaces into ones where the sound of students' voices is heard. This is a classroom that cherishes student expression, student opinion and student experience. Indeed this is a classroom which embodies those essential dimensions of democratic culture - the capacity to think, question and challenge what has been accepted and unquestioned, and to bring into the common space the diverse perspectives, beliefs and understandings of this young and emerging heterogeneous citizenry. In this space the goal is always that of an education which nurtures the independent mind and the insistent spirit of unfinished inquiry. We have been reminded again in recent times of the importance of a civic culture which refuses to passively accede to voices of authority and expertise whether in government, church or religious authority, the mass media or transnational business. We face unprecedented dangers and crises as a human race. The times demand an education that equips us with the capacity to speak up and speak out; to question and challenge what, in so many areas of our global community, is a culture of human and environmental destruction, social injustice, violence and death. The late American Philosopher Maxine Greene (Greene, 1988) refers to the German expression Es Muss Sein meaning "it must be" when she describes how the knowledge that is transmitted in our classrooms often conveys a fatalistic sense of permanence and inevitability. Her argument is that much of the time curriculum is constructed and taught in such a way that there is little understanding of the fact that what we know about the world is only temporary, provisional, and uncertain. How we come to know about the world indicates to the learner whether things can be other than what they appear to be. Knowledge that is understood to represent with certainty how things are invites no second look; it offers a reality that seems fixed and absolute (Caputo, 2013). It suggests a world that is the way it is, demanding only accommodation and acceptance of the social landscape before us. Greene speaks out of the passionate conviction that our understanding of who we are, and the nature of the world we inhabit, are inevitably constructions of the human imagination, always open to alternative perspectives and variable interpretations. To learn about the world in this way, she argues, is the gateway to liberating ourselves from a stultifying consciousness that demands acceptance of only a single right way of understandingone which is usually guarded and protected, as well often manufactured, by those whose power and privilege depends on it. To educate against the inevitability of war, violence and brutality means refusing the consciousness that says things must be this way.

Sadly our schools do little to liberate the mind from subservience to fixity of thought. Few students are ever invited in to recognize the power of interpreta- 
tion in making so-called 'truth.' Instead they are daily bombarded by the message to give 'only the facts,' the need for the single correct answer, and the certainty of the text. The great educator Paulo Freire showed us what it means when students recognize that the reality we live in and through is only one of several possibilities (Freire, 1998) There is nothing absolute and inevitable about a world that hurts and destroys the lives of so many.

The Greek concept of hermeneutical truth recognizes that what we know is always an act of interpretation has both liberating and troubling consequences. We have seen above the way that this can free us to re-envisage our lives and our world. But much more difficult is the fact that it also gives legitimacy to the conflicting ways we may see things. From this point of view there is no 'God's eyeview' of reality, only the sometimes contradictory understanding that people have of events, situations, and human motives. The decades old conflict between Palestinians and Jews provides a too vivid example of what I am proposing. In that blood-soaked region the inhabitants bring their own painful narratives to explain the need to fight and defend what they see as rightfully theirs. For the Jews it is the tortured history of exclusion, persecution and genocide, and the belief that their state is legitimated by ancient connection to the land and by moral claims rooted in their catastrophic history. For Palestinians their claims come from the conviction that the Jews, like other colonial invaders, wrongfully expropriated their land and forcefully expelled its inhabitants. We can see in other parts of the world such as Ireland, Sri Lanka, Kashmir, Iraq, the Ukraine, similar kinds of near intractable conflicts rooted in fundamentally different accounts of history and present realities. As Sartre once noted, human beings are condemned to meaning. Meaning provides the resources through which human identity is constructed. We can no more dispense with the quest for meaning than we can eradicate our need for food and water. Yet we must be attentive to the dangers of meaning making that depend on hatred of the other, racism, tribalism, extreme nationalism, religious fanaticism. And we must educate to be aware of the way social changes fan the flames of dangerous meaning making; how unregulated capitalism destroys traditional communal structures and values, the influx of foreign workers or refugees with their different beliefs, dress, etc., causes panic among local populations, failed ideologies of socialism or nationalism leaves a cultural space in which other angry and violent beliefs emerge to replace them, or resentment of western power and influence produces an irrational hostility to modernity with its commitment to freedom, choice, pluralism, gender equality, democratic norms of conflict resolution, and the production of knowledge through unrestricted critical interrogation of thought and experience.

Nothing could be more important to the task of peace education than the capacity to understand something about the way conflict is constructed out of the 
differing ways we come to see our lives and our world (Hahn, 2004). And to learn from this something about the way conflict can be mediated. From a pedagogic standpoint it means a number of things: 1) The ability and willingness to honestly articulate and communicate to others one's view of things; 2) It means the development of the capacity for active, non-judgmental, listening to the other, even when what is being communicated is painful or threatening to the listener; 3) It means the readiness, for each party, to 'walk in the others' shoes' - to be empathic to the other's situation even as this requires confronting one's own fears, resentments and anger about what is being expressed. The ability to communicate, hear, empathize, and to not be captured by our own need to deny or resist another's truth, is of course, more than a one semester high school class! Indeed it is the challenge of a lifetime for all of us. It is a task that is always before us in our collective lives as we deal with conflicts and differences of perception around things like race and ethnicity, sexuality, religious belief and politics. No preparation in school can ever equip us adequately to deal with all of this. Yet we might at least find in our education some insights, recognitions and skills that will help us to non-violently negotiate and accommodate the inevitable struggles and challenges in our world as social and political creatures 'condemned', as we are, to make meaning from our disparate experiences.

\section{Educating for compassion and empathy}

The fourth element of my pedagogy draws on the ecological concept of 'a world out of balance'. I believe that no term better captures the harmful effects on life of our present culture than this. In every area of our world we see how we have become addicted to the culture of winning, competition and success - sport, entertainment, education, science, jurisprudence, politics and of course work and the economy. In every field beating others becomes the driving force of human activity. The goal of almost every area of our lives is to outshine the next person - to succeed or to be ahead of others (Klein, 2014). Life is increasingly experienced as a race in which only the winners really matter, or deserve recognition and appreciation. More and more the marketplace becomes the root metaphor for how we live, with its overwhelming emphasis on competition, selfinterest and self-aggrandizement (Korten, 2006).

No place does more to prepare us for this way of life and this consciousness than schooling. Schools are the great initiator for a younger generation of what it means to live in a world in which everything is measured by one ability to compete with other human beings. It is here we are introduced into the moral econ- 
omy of scarcity. We learn that success and achievement for some demands that others be designated failures. To become 'somebody,' we learn means that others must count as 'nobodies.' The deep message (the 'hidden curriculum' some call it) of schooling is that the only things that count are the things that can be counted because they allow us to be ranked and compared to others on a scale of winning and losing (Purpel, 2004). Here, as elsewhere in our world, our focus is turned so resolutely to the winners that we lose little time in noticing the deeper moral, social and emotional consequences of our choices. The way, for example, the relentless emphasis on success for some produces a culture with powerful currents of envy, resentment, and suspicion. For everyone this is a culture that cultivates a deep insecurity about our worth as we are constantly being judged and compared to others, and where success or achievement is likely to be a momentary phenomenon. It is culture that must certainly breed hostility and aggression.

The human impulse to compete is certainly very deep (though it seems more embedded in males than females) and it brings with it undoubted pleasures. Yet we have produced a world out of balance; a world where getting ahead matters much more than getting along, where competition matters much more than community, and where sorting people out is more important than social solidarity (Judt, 2010). Education can make a major contribution to this more balanced way of existence. We can try to make our classrooms or schools places less ruled by competition (admittedly not easy in this time of intense focus on standardized tests). We can articulate and practice a philosophy in which individual grades and test results are not what we value most. We can facilitate more time for group and peer-supported activity. We can try cultivating a social ambience in our classroom or school in which caring, compassionate and supportive relationships are important and social divisions are lessened, and where racism, sexism, homophobia and other forms of social prejudice are not tolerated (Noddings, 2013). And we can ensure that our curriculum gives at least equal time to social movements and events that enhance community and solidarity in our nation and globally. Obviously we cannot as educators eliminate the culture of competition and selfish individualism. But we can enable young people to at least experience what it means to spend time in a community that cares and supports all, and emphasizes the importance of cooperative and reciprocal relationships. In this way education might contribute towards the goal of how we might live, both individually and collectively, more balanced lives.

\section{Educating for hope and possibility}

In conclusion, and my fifth and final point, is that a critical pedagogy of peace emphasizes the importance of hope. Hope, I have no doubt, is an essential ingre- 
dient of change. Unlike some versions of Marxist thought there is no automatic, determined process by which human society moves from one stage to another. Change requires not just some understanding or grasp of what ails a culture but also a sense that something else is possible, that things do not have to stay as they are. There has to be a positive energy that says our efforts at changing the way the things are can really bear fruit - the extraordinary could really happen. Hope seems to combine this sense of unlikely possibility with other things such as courage, imagination, faith, a sense of history, and that elusive quality called grace. Hope cannot be confused with optimism which is the disposition to expect things to out fine. Hope is that unlikely quality that allows us to believe that this suffering is not our necessary destiny or fate. Things can really be otherwise. A different kind of existence can come into being (Welch, 2004).

The question here for us is can hope be taught? I am encouraged to believe like Paolo Freire that there is a pedagogy of hope. And that certain things can indeed nourish this quality. One of these is knowing something about history. Not in the dead and disconnected way we usually teach it in school, but as the living struggle by human beings, often against all odds, to win greater justice, freedom or opportunity, or to stop a war. When history is taught as the memory of these impossible struggles students are opened to the recognition that people at other times struggled to make change when such change seemed entirely unlikely, when the forces arrayed against them made it seem as if this was a futile quest. In my pedagogy I attempt to make students see the 'present as history'; to see our present struggles for social justice, an end to war, fair trade, a sustainable economy and climate as unlikely - or as likely - as other previous 'impossible' quests.

It is helpful, of course, when our education emphasizes the constructed nature of knowledge. In this sense we help to break to breakdown the 'tyranny of facts' which seems to make reality such an unmovable force. To see that the way we know and understand the world is but one possibility among many opens the door to questioning whose 'reality' is this, and in whose interests is it for us to apprehend the world in this particular way. There is nothing that is fixed and unmovable about the world. We need just the imagination to reconceptualize it. Such thinking nourishes the sense of possibility among students. The invitation to see the world in new ways, the sense that history was about the struggles of men and women to change their world especially if this is accompanied by students' own involvement in struggles for peace and social justice, can go a long way towards overcoming a sense of fatalism, cynicism or apathy among young people, and encouraging a powerful sense of hope and belief in the possibility that we may really live a world of greater peace, justice and understanding. In these troubled times, I believe, there is no greater responsibility for educators than to articulate and encourage such a vision for education. 


\section{Literatura}

Aronowitz S. (2008). Against Schooling. New York.

Bauman Z. (2007). Liquid Times. Cambridge.

Caputo J. (2013). Truth. London.

De Graaf J., et. al. (2005). Affluenza. San Francisco.

Eisler R. (2008). The Real Wealth of Nations. San Francisco.

Freire P. (1998). Pedagogy of Freedom. Lanham, MD.

Giroux H. (2001). Theory and Resistance in Education. Westport, Conn.

Giroux H. (2011). On Critical Pedagogy. New York.

Greene M. (1988). The Dialectic of Freedom. New York.

Hacker J. (2006). The Great Risk Shift. New York.

Hahn T.N. (2004). Peace Begins Here. Berkeley.

Hooks B. (2010). Teaching Critical Thinking. New York.

Judt T. (2010). Ill Fares the Land. New York.

Klein N. (2014). This Changes Everything. New York.

Korten D. (2006). The Great Turning. San Francisco.

Lerner M. (2006). The Left Hand of God. San Francisco.

Noddings N. (2013). Education and Democracy in the $21^{\text {st }}$ Century. New York.

Palmer P. (2004). A Hidden Wholeness. San Francisco.

Purpel D. (2004). Reflections on the Moral and Spiritual Crisis of Education. New York.

Ravitch D. (2014). Reign of Error. New York.

Sachs J. (2005). The End of Poverty. New York.

Salamon G., Nevo B. (2002). Peace Education. New Jersey.

Shapiro S. (2006). Losing Heart: The Moral and Spiritual Crisis of America's Children Mahwah N.J.

Shapiro S. (2009). Education and Hope in Troubled Times. New York.

Shapiro S. (2010). Educating Youth for a World Beyond Violence. New York.

Tutu D. (1999). No Future Without Forgiveness. New York.

Welch S. (2004). After Empire. Minneapolis.

West C. (2004). Democracy Matters. New York.

\section{W stronę pedagogiki kryłycznej edukacji dla pokoju}

\section{Streszczenie}

Edukacja dla pokoju jest zawsze procesem całościowym. Oznacza ona rozpoznanie w człowieku zdolności do przejścia w stronę mniej gwałtownej i jednocześnie bardziej kooperatywnej formy egzystencji. Niestety, w przypadku form edukacji realizowanych obecnie w wielu szkołach taka zmiana jest trudna do przeprowadzenia. Dzieje się tak chociażby z tego względu, że edukacja insty- 
tucjonalna zorientowana jest głównie na mierzalne osiągnięcia, a odrzuca wszystko to, czego nie można zamienić na policzalne dane. Tego rodzaju system kształcenia opiera się bowiem na silnie uproszczonym modelu człowieka, w którym nie poszukuje się odpowiedzi na kluczowe pytania natury humanistycznej. Niemniej w kwestii edukacji dla pokoju odnaleźć możemy kilka zasadniczych elementów wskazujących na możliwość innego spojrzenia na problem harmonijnego współżycia. Elementy te wywodzą się chociażby z innych aniżeli europejskie systemów kulturowych. Pierwszym z tego typu elementów jest pojęcie ubuntu, które spotkać możemy w Republice Południowej Afryki. W najszerszym znaczeniu odnosi się ono do przekonania, że jednostka ludzka nie może rozwijać się w izolacji od innych. Ta myśl stoi w opozycji do zachodniego indywidualizmu, który obecnie jest silnie uwypuklony poprzez różnego rodzaju praktyki kulturowe. Zastosowanie tej koncepcji w praktyce szkolnej rzutuje na inne spojrzenie na potrzeby ucznia rozumiane w wymiarze moralnym, społecznym i duchowym. Przesłanie edukacyjne, jakie niesie ze sobą ubun$t u$, stanowi twierdzenie, iż należy stawiać opór wszelkim kwestiom przyczyniającym się do budowania barier pomiędzy ludźmi. Podobne znaczenie niesie ze sobą hebrajski termin tikkun olam. Ta wywodząca się z judaizmu koncepcja odnosi się z kolei do wizji świata, w którym przezwyciężone zostały wszelkie podziały, a następnie świat ten stał się całością. Oznacza ona „naprawę świata”. Można jej dokonać jedynie dzięki zaangażowaniu i pracy włożonej w ten projekt. Problemem może w tym względzie stać się jedynie ogólnie rozumiany deficyt sensów we współczesnym świecie. Obie koncepcje pozostają jednak niezmiennie we wzajemnie komplementarnej relacji wobec siebie oraz idei edukacji dla pokoju. Uzupełnia je greckie pojęcie parezji oraz tradycja hermeneutyczna. Parezja jest pojmowana jako nieustraszony głos rzucający wyzwanie i kwestionujący nieuzasadnione cierpienie na świecie. Prowadzi to nas do włączenia w obszar rozważań nad edukacją dla pokoju także modelu pedagogiki krytycznej. Ta zaś pomoże w realizacji projektu obywatela krytycznego, a wiec także obywatela podważającego obowiązujące modele kształcenia. Stawia to przed nami problemy o charakterze praktycznym i przenosi ciężar dyskusji nad projektem edukacji dla pokoju w obszar konkretnych działań, np. na płaszczyźnie klas szkolnych. Nic nie jest tak istotne w tym względzie jak możliwość zapobiegania konfliktom w tego typu mikroskali, która w dalszej kolejności pozwoli na stworzenie szerszych modeli edukacyjnych. Edukacja dla pokoju stanowi tym samym projekt pełen wyzwań, choć niepozbawiony umocowania w określonych tradycjach pedagogicznych, jak chociażby te kryjące się w pojęciach ubuntu, tikkun olam i parezja. 